\title{
Molecular Docking Studies of PA-824 with Pyridoxine 5'-Phosphate Oxidase
}

\section{Sathish Kumar $\mathbf{M}^{1^{*}}$ and Jaleel UCA ${ }^{2}$}

${ }^{1}$ CSIR OSDD Research Unit, Bangalore, India

${ }^{2}$ Bharathidasan University, Tiruchirappalli, Tamil Nadu, India

*Corresponding author: Sathish Kumar M, CSIR OSDD Research Unit, Bangalore, India, Tel: 0431 240 7072; E-mail: msathishkumara@gmail.com

Received date: December 02, 2015; Accepted date: January 28, 2016; Published date: February 01, 2016

Copyright: (C) 2016 Kumar MS, et al. This is an open-access article distributed under the terms of the Creative Commons Attribution License, which permits unrestricted use, distribution and reproduction in any medium, provided the original author and source are credited.

\begin{abstract}
Mycobacterium tuberculosis is to be one of the world's most deadly pathogens. The PA-824 nitroimidazole is a prodrug with an action activity against both hypoxic and replicating of Mycobacterium tuberculosis. PA-824 molecule was activated by a cofactor, which is a compound that binds to a protein. This prodrug was used as a ligand to bind with the protein PDB ID: 1XXO (Pyridoxine 5'-phosphate oxidase complexed with pyridoxal 5'-phosphate). Pyridoxine 5-phosphate oxidase is called as the enzyme that catalyzes the B6 metabolism pathway by limits the rate step process. Docking analysis was performed on the protein 1XX0 along with ligand PA-824 using Autodock.
\end{abstract}

Keywords: Docking; Pocket site; PA-824

\section{Introduction}

Tuberculosis is a major disease that is caused by Mycobacterium tuberculosis. Tuberculosis primarily affects the lungs, affecting the bone, the central nervous system, lymphatic system, and circulatory system among others. In past years disease was called as consumption, because it can be consumed by the person who was infected by Mycobacterium tuberculosis [1]. Since a person affected with tuberculosis, the bacteria in the lungs multiply and cause pneumonia along with severe chest pain, coughing blood, and a long time cough. Additionally, lymph nodes near the heart and compare to average size lungs becomes significant. As tuberculosis tries to spread to the body parts, it is often interrupted by the body's immune system [2]. The host immune system forms scar tissue or fibrosis around the tuberculosis bacteria, and this helps fight infection and protects the disease from spreading throughout the body and to other people.

PA-824 is a prodrug drug that is undergoing experiment as a potential treatment for Tuberculosis. PA-824 is major compound, unproductive activity against tuberculosis. Nitroimidazole has also shown activity against both active and latent tuberculosis. In a past year agreement with biotechnology company called Chiron, the tuberculosis alliance is carrying out phase II clinical testing on PA-824 is most active molecule against latent Tuberculosis bacteria. In a quiescent state, bacteria are anaerobic and else replicating very slowly and non-replicating. In 2008, researchers belonging to NIAID found that Nitroimidazoles kills mtb bacteria by releasing nitric oxide, which is highly poisonous to bacteria. PA- 824 mimics the body's immune response, but it is real specific and releasing the gas upon entering of the tuberculosis bacteria.

Pyridoxine 5-phosphate oxidase is an enzyme, homodimer, that the disulfide bonds connect the two monomers. Salt-bridge interactions between the two monomers are determined. Each subunit tightly attaches to one molecule of pyridoxal 5'-phosphate. Secondary structures identified in the protein motif region, which is graphical represented as a split-barrel structure. The enzyme needs the presence of a cofactor, flavin mononucleotide, for enzyme activity. The flavin mononucleotide is in a profound cloven formed by polypeptide subunits and held in place by hydrogen bond interactions with the protein. In this special case, the FMN assists the enzyme and substrates binding. The active site of the pyridoxal 5'-phosphate is in a fastened conformation because, the absence of pyridoxal 5-phosphate. After substrate binds to the receptor molecule and is converted to PLP. Particular amino acids are responsible for the hydrogen bonds are forming in PLP, forming a lid around the active site, increase to the near conformation.

\section{Materials and Methods}

The present study is performed using bioinformatics tools, biological databases like PubMed, PDB (Protein Data Bank) and software like Autodock, chimera.

\section{Ligand structure}

PA-824 is a primary anti-tuberculosis drug. It is active compound against Mycobacterium tuberculosis. In the year, 2008 scientists and researchers from the National Institute of Allergy and Infectious Diseases found that PA-824 destroys Mycobacterium tuberculosis bacteria by releasing nitric oxide, which poisons to bacteria (Figure 1). This compound was retrieved from the PubChem database.

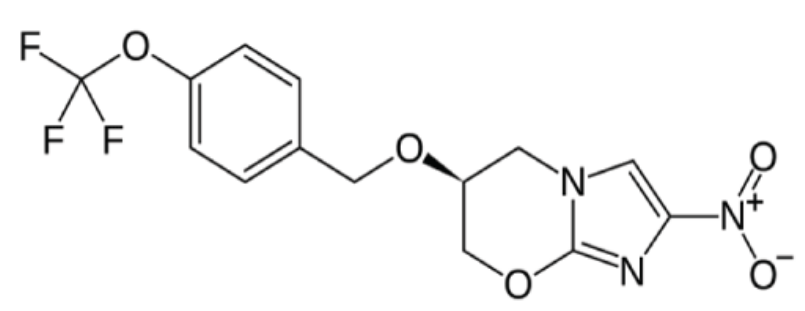

Figure 1: Ligand Structure of PA-824. 
Page 2 of 4

\section{Protein structure preparation}

For the molecular docking studies, Pyridoxine 5 phosphate oxidase protein structure was taken from the Protein Databank Database (Figure 2). Flavin mononucleotide (FMN) is a coenzyme necessary for enzyme activity, and FMN is identified in the cleft region, and its helps the enzyme to bind the substrates. Pyridoxine 5 phosphate oxidase structure PDB ID was 1XXO. For the protein structure, all hydrogen atoms are added and add gassier charges to the protein for docking simulation analysis. Pocket Finder is an online server used for identifying the binding sites of a macromolecule.

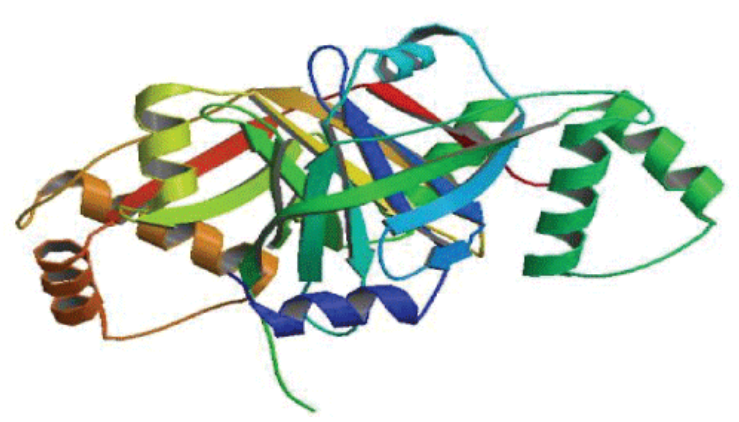

Figure 2: Structure of Pyridoxine 5 phosphate oxidase (PDB ID: 1XXO).

\section{Active site prediction}

Pocket Finder is a pocket detection algorithm based on the ligsite written by Hendlich et al. [3]. Pocket Finder works by a scanning a probe radius 1.6 angstroms along all grid lines of a grid resolution of about 0.9 angstroms surrounding the protein [4].

\section{Docking protocol}

The docking calculation was executed by using Autodock. Grid maps with $60^{*} 60^{\star} 60$ points were made and the grid point spacing of 0.3 angstroms. The best conformation was chosen with the lower docking energy [5]. Cygwin is used for to execute the auto grid and auto dock files. Chimera software predicts the Binding interaction of complex pyridoxine 5-phosphate oxidase and PA-824 conformations including hydrogen bond and the bond length $[6,7]$.

\section{Results and Discussion}

\section{Docking analysis result}

Pyridoxine 5 Phosphate Oxidase, the macromolecule, and the ligand molecule were subject to docking analysis using Autodock software. Genetic Algorithm (GA) 10 docking runs were performed (Figure 3). Grid parameter was set as mentioned earlier and the grid spacing point was $60^{\star} 60^{\star} 60$. After final docking analysis, the docked structure with ligands was analyzed protein-ligand interactions [8-10]. Hydrogen bond interactions and the binding energy of the protein and ligand molecule were performed.

Every pocket has many binding sites, totally ten pockets (Pockets 1-10). Docking analysis of PA-824 is performed with different binding sites of pyridoxine five phosphate oxidase. The binding free energy and the hydrogen bonds between the ligand and the macromolecule are shown below (Table 1).

\begin{tabular}{|c|c|c|c|c|c|}
\hline Residues & Free energy of binding & $\begin{array}{l}\text { No of } \mathrm{H}- \\
\text { bonds }\end{array}$ & Residues & Free energy of binding & No of H-bonds \\
\hline \multicolumn{3}{|l|}{ Pocket 1} & \multicolumn{3}{|l|}{ Pocket 2} \\
\hline LEU A 22 & $5.22 \mathrm{kcal} / \mathrm{mol}$ & 1 & TRP A 77 & $-5.32 \mathrm{kcal} / \mathrm{mol}$ & 1 \\
\hline THR A 24 & $-4.17 \mathrm{kcal} / \mathrm{mol}$ & 2 & ASN B 35 & $-5.51 \mathrm{kcal} / \mathrm{mol}$ & 4 \\
\hline GLN A 32 & $-4.70 \mathrm{kcal} / \mathrm{mol}$ & 2 & VAL B 36 & $-5.55 \mathrm{kcal} / \mathrm{mol}$ & 2 \\
\hline SER A 34 & $-5.58 \mathrm{kcal} / \mathrm{mol}$ & 4 & GLN B 37 & $-5.76 \mathrm{kcal} / \mathrm{mol}$ & 2 \\
\hline VAL A 36 & $-5.52 \mathrm{kcal} / \mathrm{mol}$ & 4 & TYR B 38 & $-5.32 \mathrm{kcal} / \mathrm{mol}$ & 1 \\
\hline GLN A 37 & $-5.72 \mathrm{kcal} / \mathrm{mol}$ & 4 & VAL B 49 & $-5.60 \mathrm{kcal} / \mathrm{mol}$ & 4 \\
\hline SER A 50 & $-5.92 \mathrm{kcal} / \mathrm{mol}$ & 2 & SER B 50 & $-5.82 \mathrm{kcal} / \mathrm{mol}$ & 2 \\
\hline ILE A 51 & $-5.71 \mathrm{kcal} / \mathrm{mol}$ & 5 & ILE B 51 & $-5.71 \mathrm{kcal} / \mathrm{mol}$ & 4 \\
\hline ALA A 52 & $-5.57 \mathrm{kcal} / \mathrm{mol}$ & 4 & ALA B 52 & $-5.51 \mathrm{kcal} / \mathrm{mol}$ & 3 \\
\hline GLU A 53 & $-5.02 \mathrm{kcal} / \mathrm{mol}$ & 4 & LEU B 103 & $-5.87 \mathrm{kcal} / \mathrm{mol}$ & 2 \\
\hline LYS A 57 & $-5.35 \mathrm{kcal} / \mathrm{mol}$ & 1 & ILE B 110 & $-4.97 \mathrm{kcal} / \mathrm{mol}$ & 0 \\
\hline THR A 58 & $-5.37 \mathrm{kcal} / \mathrm{mol}$ & 2 & TYR B 120 & $-5.76 \mathrm{kcal} / \mathrm{mol}$ & 2 \\
\hline LEU A 106 & $-5.98 \mathrm{kcal} / \mathrm{mol}$ & 2 & MET B 124 & $-4.25 \mathrm{kcal} / \mathrm{mol}$ & 3 \\
\hline
\end{tabular}


Citation: Kumar MS, Jaleel UCA (2016) Molecular Docking Studies of PA-824 with Pyridoxine 5'-Phosphate Oxidase. Biol Med (Aligarh) 8: 274. doi:10.4172/0974-8369.1000274

Page 3 of 4

\begin{tabular}{|c|c|c|c|c|c|}
\hline TYR A 107 & $-5.69 \mathrm{kcal} / \mathrm{mol}$ & 3 & ARG B 129 & $-5.89 \mathrm{kcal} / \mathrm{mol}$ & 2 \\
\hline ARG A 129 & $-6.06 \mathrm{kcal} / \mathrm{mol}$ & 2 & \multicolumn{3}{|l|}{ Pocket 4} \\
\hline TYR B 79 & $-4.81 \mathrm{kcal} / \mathrm{mol}$ & 1 & LEU A 22 & $-5.34 \mathrm{kcal} / \mathrm{mol}$ & 2 \\
\hline ARG B 147 & $-4.71 \mathrm{kcal} / \mathrm{mol}$ & 0 & ILE A 47 & $-4.63 \mathrm{kcal} / \mathrm{mol}$ & 1 \\
\hline \multicolumn{3}{|l|}{ Pocket 3} & GLN A 48 & $-5.68 \mathrm{kcal} / \mathrm{mol}$ & 5 \\
\hline ASN A 17 & $-4.87 \mathrm{kcal} / \mathrm{mol}$ & 2 & VAL A 49 & $-5.88 \mathrm{kcal} / \mathrm{mol}$ & 2 \\
\hline ILE A 19 & $-4.81 \mathrm{kcal} / \mathrm{mol}$ & 2 & ILE A 69 & $-4.75 \mathrm{kcal} / \mathrm{mol}$ & 2 \\
\hline GLY A 20 & $-5.36 \mathrm{kcal} / \mathrm{mol}$ & 1 & LEU A 132 & $-5.55 \mathrm{kcal} / \mathrm{mol}$ & 4 \\
\hline VAL A 21 & $-5.44 \mathrm{kcal} / \mathrm{mol}$ & 1 & LEU A 134 & $-5.51 \mathrm{kcal} / \mathrm{mol}$ & 3 \\
\hline ASN A 35 & $-5.53 \mathrm{kcal} / \mathrm{mol}$ & 4 & \multicolumn{3}{|l|}{ Pocket 6} \\
\hline LEU A 70 & $-5.28 \mathrm{kcal} / \mathrm{mol}$ & 1 & GLN B 48 & $-4.33 \mathrm{kcal} / \mathrm{mol}$ & 2 \\
\hline VAL A 71 & $-4.75 \mathrm{kcal} / \mathrm{mol}$ & 1 & ALA B 102 & $-3.41 \mathrm{kcal} / \mathrm{mol}$ & 0 \\
\hline ASP A 72 & $-5.03 \mathrm{kcal} / \mathrm{mol}$ & 1 & LEU B 106 & $-6.52 \mathrm{kcal} / \mathrm{mol}$ & 2 \\
\hline ALA A 73 & $-4.85 \mathrm{kcal} / \mathrm{mol}$ & 2 & ASN B 109 & $-4.62 \mathrm{kcal} / \mathrm{mol}$ & 2 \\
\hline GLY A 76 & $-4.95 \mathrm{kcal} / \mathrm{mol}$ & 1 & \multicolumn{3}{|l|}{ Pocket 7} \\
\hline SER A 78 & $-4.95 \mathrm{kcal} / \mathrm{mol}$ & 1 & LEU B 22 & $-5.73 \mathrm{kcal} / \mathrm{mol}$ & 2 \\
\hline ASN B 17 & $-5.03 \mathrm{kcal} / \mathrm{mol}$ & 1 & ILE B 47 & $-5.69 \mathrm{kcal} / \mathrm{mol}$ & 1 \\
\hline GLY B 20 & $-6.30 \mathrm{kcal} / \mathrm{mol}$ & 2 & VAL B 49 & $-6.46 \mathrm{kcal} / \mathrm{mol}$ & 2 \\
\hline VAL B 21 & $-5.60 \mathrm{kcal} / \mathrm{mol}$ & 2 & ALA B 67 & $-4.25 \mathrm{kcal} / \mathrm{mol}$ & 2 \\
\hline ASN B 35 & $-5.37 \mathrm{kcal} / \mathrm{mol}$ & 2 & ILE B 69 & $-4.73 \mathrm{kcal} / \mathrm{mol}$ & 2 \\
\hline TRP B 77 & $-4.75 \mathrm{kcal} / \mathrm{mol}$ & 1 & LEU B 132 & $-6.44 \mathrm{kcal} / \mathrm{mol}$ & 2 \\
\hline \multicolumn{3}{|l|}{ Pocket 5} & \multicolumn{3}{|l|}{ Pocket 8} \\
\hline ARG A 30 & $-4.10 \mathrm{kcal} / \mathrm{mol}$ & 2 & ASP B 41 & $-4.59 \mathrm{kcal} / \mathrm{mol}$ & 1 \\
\hline PRO A 31 & $-3.64 \mathrm{kcal} / \mathrm{mol}$ & 4 & LYS B 44 & $-3.93 \mathrm{kcal} / \mathrm{mol}$ & 1 \\
\hline ALA B 23 & $-5.50 \mathrm{kcal} / \mathrm{mol}$ & 3 & LEU B 46 & $-3.55 \mathrm{kcal} / \mathrm{mol}$ & 4 \\
\hline THR B 24 & $-3.74 \mathrm{kcal} / \mathrm{mol}$ & 2 & GLN B 48 & $-4.67 \mathrm{kcal} / \mathrm{mol}$ & 0 \\
\hline ILE B 25 & $-3.62 \mathrm{kcal} / \mathrm{mol}$ & 3 & \multicolumn{3}{|l|}{ Pocket 10} \\
\hline ARG B 66 & $-3.28 \mathrm{kcal} / \mathrm{mol}$ & 0 & ALA A 23 & $-5.18 \mathrm{kcal} / \mathrm{mol}$ & 2 \\
\hline ALA B 67 & $-4.31 \mathrm{kcal} / \mathrm{mol}$ & 2 & ARG A 66 & $-3.26 \mathrm{kcal} / \mathrm{mol}$ & 2 \\
\hline \multicolumn{3}{|l|}{ Pocket 9} & ALA A 67 & $-3.95 \mathrm{kcal} / \mathrm{mol}$ & 1 \\
\hline TYR A 79 & $-5.03 \mathrm{kcal} / \mathrm{mol}$ & 2 & SER A 68 & $-4.73 \mathrm{kcal} / \mathrm{mol}$ & 3 \\
\hline GLN B 32 & $-4.29 \mathrm{kcal} / \mathrm{mol}$ & 1 & ARG B 30 & $-3.86 \mathrm{kcal} / \mathrm{mol}$ & 3 \\
\hline SER B 34 & $-5.30 \mathrm{kcal} / \mathrm{mol}$ & 2 & & & \\
\hline LYS B 57 & $-6.17 \mathrm{kcal} / \mathrm{mol}$ & 6 & & & \\
\hline
\end{tabular}

Table 1: Pockets showing their different residues, free energy of binding and H-bonds (Pockets 1-10). 


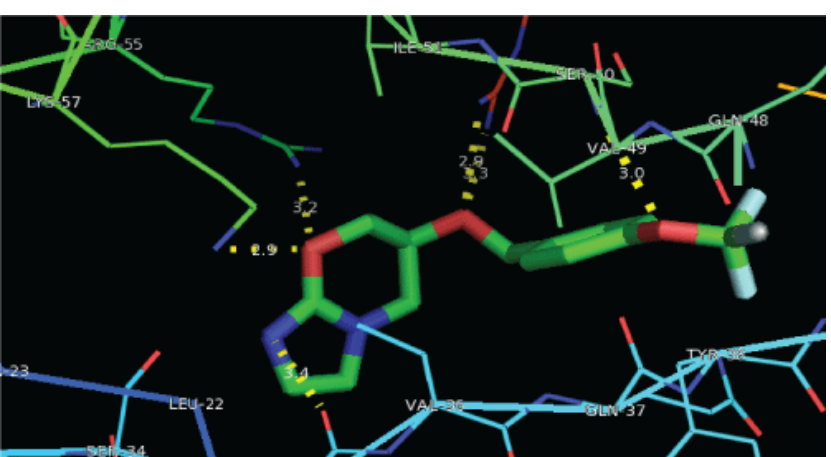

Figure 3: Docking pose of PA-824 with Pyridoxine 5 phosphate oxidase (PDB ID : 1XXO).

\section{Conclusion}

The binding interaction between the protein ligand molecule is important to structural based drug design [11]. The present study investigation revealed that the analysis of differences in residue sites and various pockets. And the analysis is carried out the best pocket site pyridoxine 5-phosphate oxidase with PA824 molecule. LYS B 57 is a best pocket site with a Free energy binding of $-6.17 \mathrm{kcal} / \mathrm{mol}$ and $6 \mathrm{H}$ bonds interactions between the target protein and Molecule. This site could be the best possible to inhibit the process in Mycobacterium tuberculosis. We finally concluded the best pocket site for the PA-824 and the data are computationally framework for further analysis.

\section{Acknowledgement}

This work carried out at CSIR OSDD Research Unit, Indian Institute of science. I also thank my Guide Dr. UCA Jaleel and my friends.

\section{References}

1. Barry CE 3rd, Boshoff HI, Dowd CS (2004) Prospects for clinical introduction of nitroimidazole antibiotics for the treatment of tuberculosis. Curr Pharm Des 10: 3239-3262.

2. Boshoff HI, Myers TG, Copp BR, McNeil MR, Wilson MA, et al. (2004) The transcriptional responses of Mycobacterium tuberculosis to inhibitors of metabolism: novel insights into drug mechanisms of action. J Biol Chem 279: 40174-40184.

3. Boshoff HI, Barry CE 3rd (2005) Tuberculosis - metabolism and respiration in the absence of growth. Nat Rev Microbiol 3: 70-80.

4. Brunori M, Forte E, Arese M, Mastronicola D, Giuffrè A, et al. (2006) Nitric oxide and the respiratory enzyme. Biochim Biophys Acta 1757: 1144-1154.

5. Darwin KH, Ehrt S, Gutierrez-Ramos JC, Weich N, Nathan CF (2003) The proteasome of Mycobacterium tuberculosis is required for resistance to nitric oxide. Science 302: 1963-1966.

6. Manjunatha UH, Boshoff H, Dowd CS, Zhang L, Albert TJ, et al. (2006) Identification of a nitroimidazo-oxazine-specific protein involved in PA-824 resistance in Mycobacterium tuberculosis. Proc Natl Acad Sci U S A 103: 431-436.

7. Matsumoto M, Hashizume H, Tomishige T, Kawasaki M, Tsubouchi H, et al. (2006) OPC-67683, a nitro-dihydro-imidazooxazole derivative with promising action against tuberculosis in vitro and in mice. PLoS Med 3: e466.

8. Matteelli A, Migliori GB, Cirillo D, Centis R, Girard E, et al. (2007) Multidrug-resistant and extensively drug-resistant Mycobacterium tuberculosis: epidemiology and control. Expert Rev Anti Infect Ther 5: 857-871.

9. Rao SP, Alonso S, Rand L, Dick T, Pethe K (2008) The protonmotive force is required for maintaining ATP homeostasis and viability of hypoxic, nonreplicating Mycobacterium tuberculosis. Proc Natl Acad Sci U S A 105: 11945-11950.

10. Singh R, Manjunatha U, Boshoff HI, Ha YH, Niyomrattanakit $\mathrm{P}$, et al. (2008) PA-824 kills nonreplicating Mycobacterium tuberculosis by intracellular NO release. Science 322: 1392-1395.

11. Stover CK, Warrener P, VanDevanter DR, Sherman DR, Arain TM, et al. (2000) A small-molecule nitroimidazopyran drug candidate for the treatment of tuberculosis. Nature 405: 962-966. 